\title{
قوة تحمل الشخصية لدى المشرفين التربويين
}

\section{د. دئ ناصر خليفة}

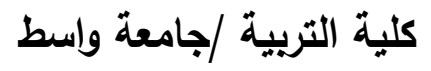

(الفصل

التعريف بالبحث

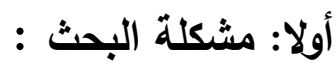

يعيش الإنسان في حياة مليئة بالضغوطات المهنية والاجتماعية والنفسية وما يترتب عليها العديد من الإمراض والاضطرابات النفسية والجسمية، حيث عاش الإنسان منذ بداية نشأة الكون عبر ملايين السنين

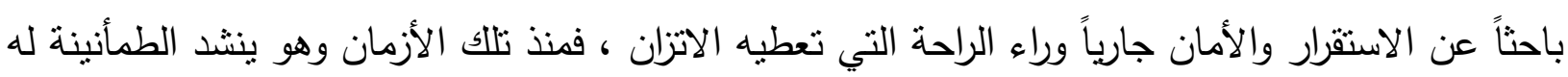

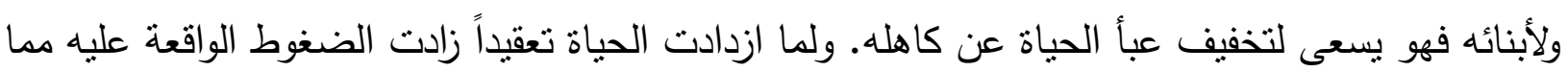

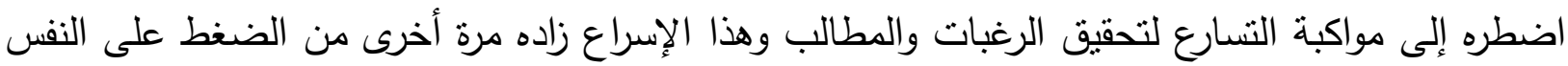

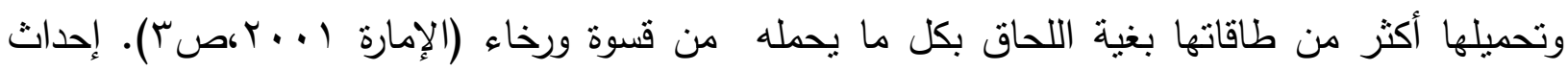

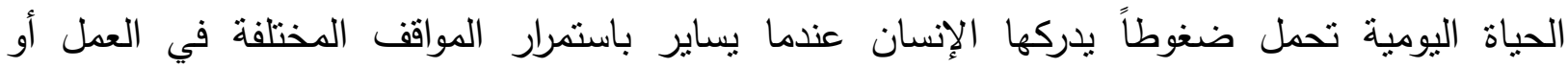

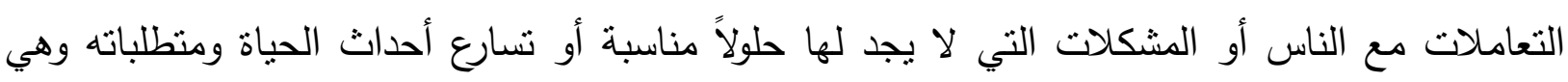

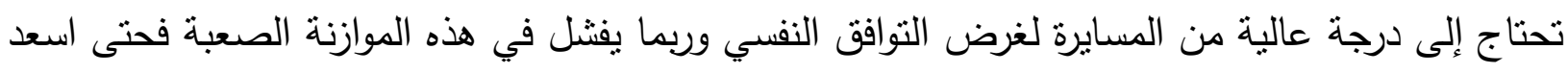

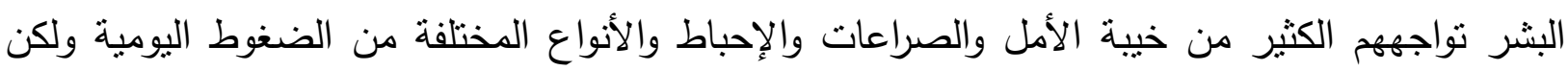

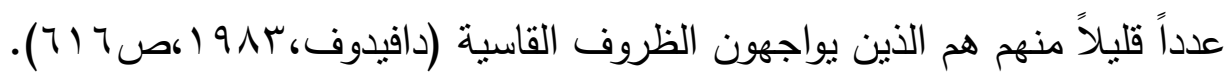
نال موضوع الضغوط اهتماماً كبيراً من لدن الباحثين لما له من أثنار سلبية على صحة الإنسان النهان النفسية

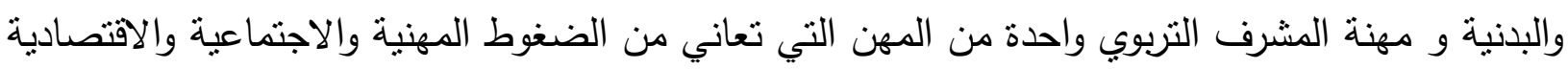

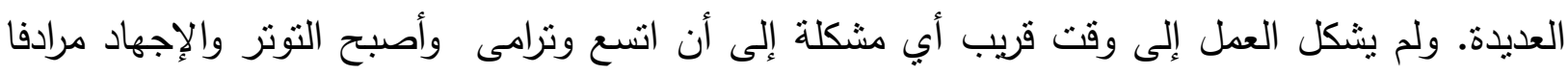

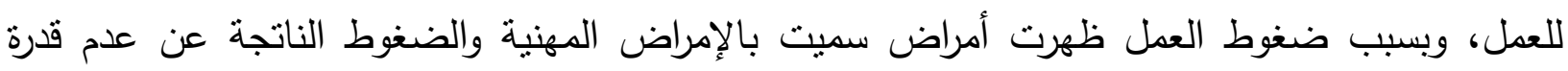

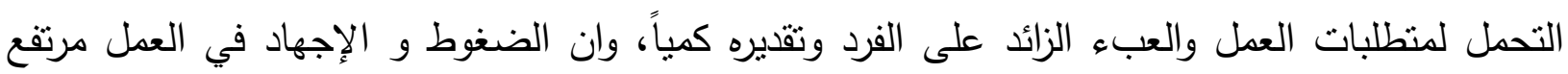

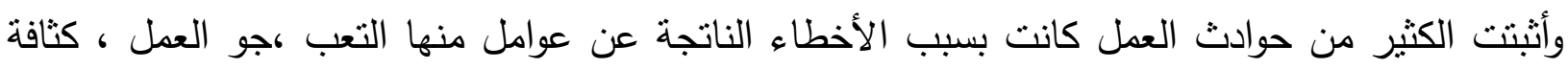

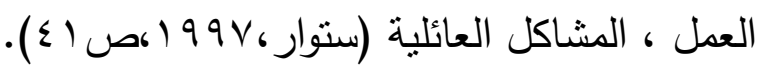

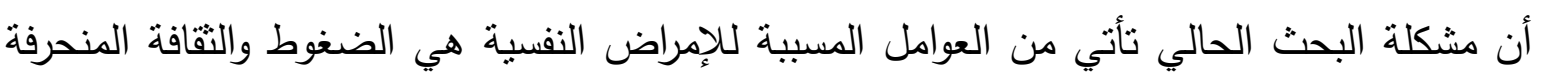

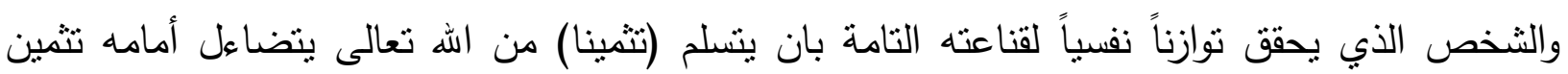

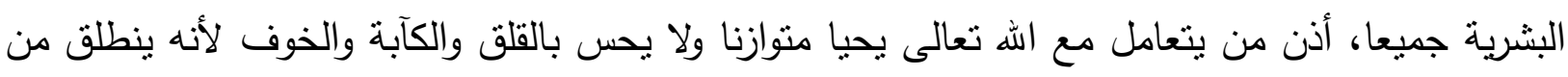

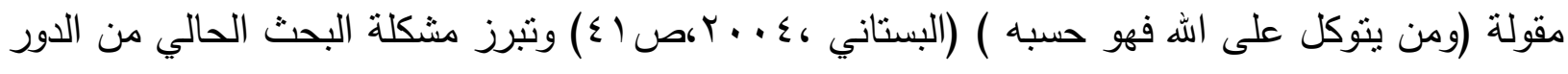
القيادي الذي يلعبه المشرف التربوي والضغوط التي يواجهها في عملية التعلم والتعليم وتحقيق الأهداف 
التربوية المرسومة التي تتطلب منه التعامل بأسلوب يكفل استمرار الحياة بنوع من الجلد والقوة والتوافق السليم مما يزيد انجازه.

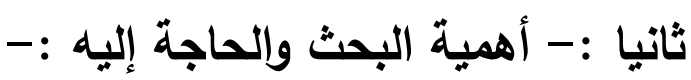
أن الإنسان هو أحسن وأرقى المخلوقات على وجه الأرض وقد ميزه اله تعالى بطاقات كثثرة وقدرات أكثر

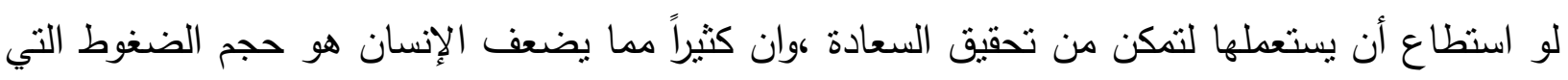

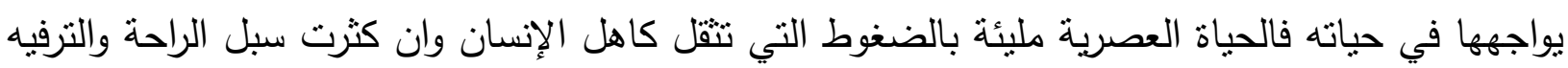

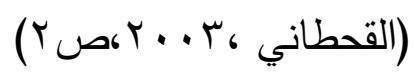
من النادر أن نجد أنسانا لايعاني من الضغوط الضغو النفسية وبخاصة تلك الناتجة من الأزمات والكوارث والحروب وانعدام الأمن النفسي والاقتصادي والحياتي والتي تؤدي إلى اختلال أجزة المراقبة والمناعة.

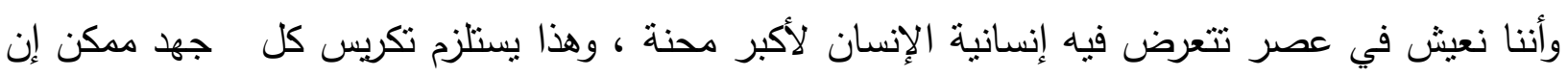

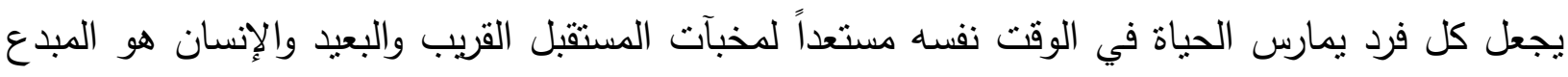

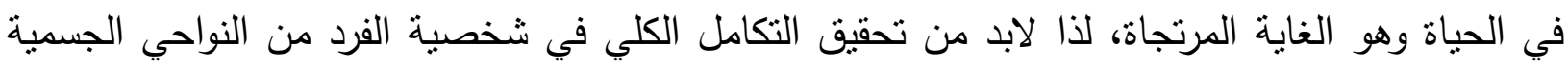

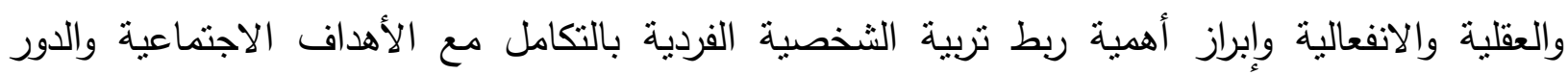

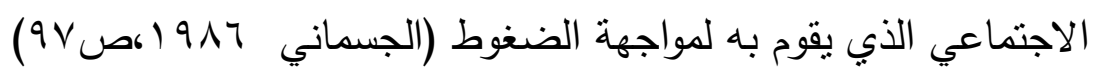

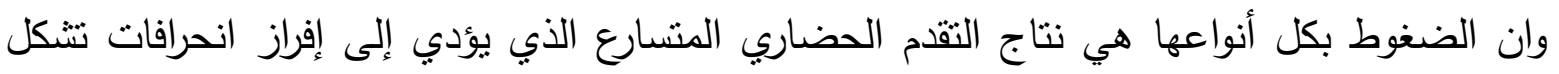

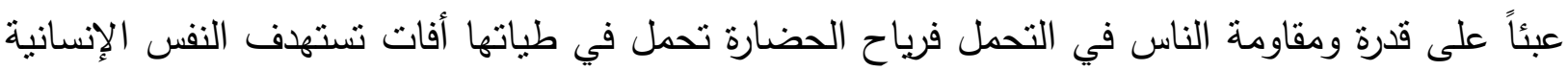

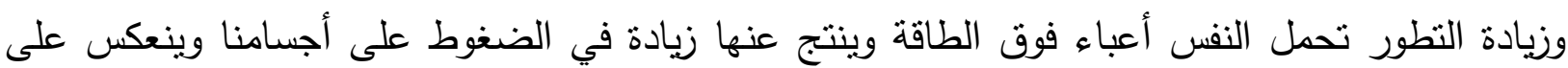

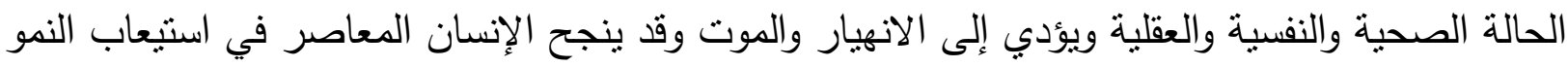

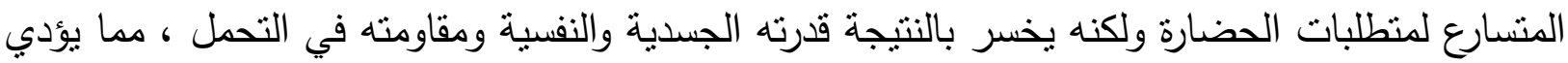

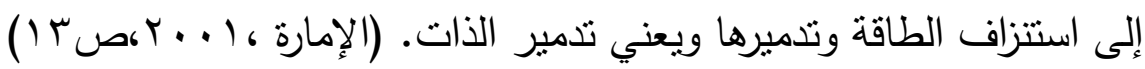

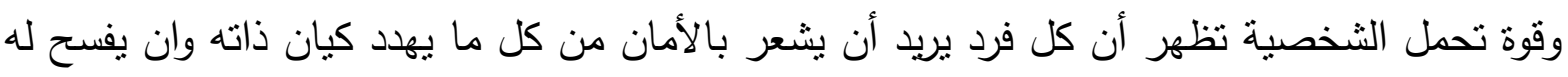

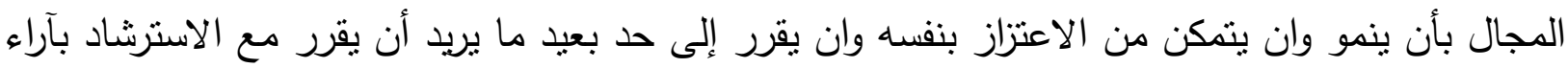

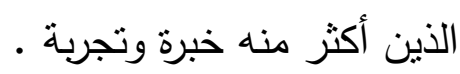

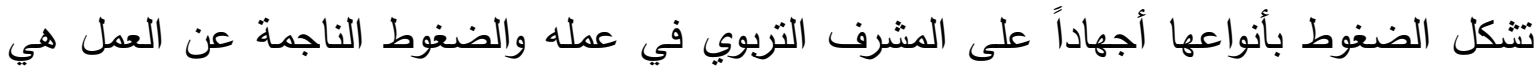
الإرهاق وساعات العمل الطويلة ونوعيته وأوقاته المختلفة وكذللك والضوضاء يدفئع إلى إلى الملل وعدم القدرة

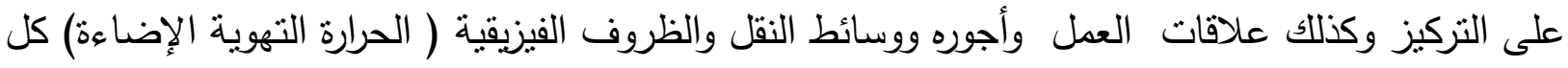

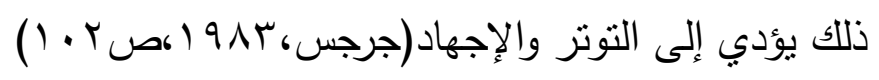

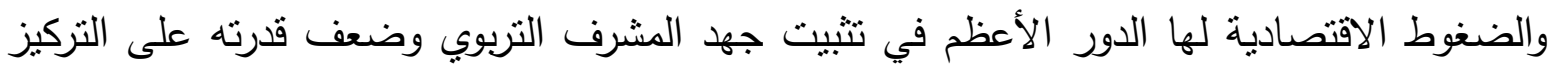
وخاصة عندما تعصف به الأزمات المالية أو الخسارة أو فقدان العمل أو يكون الأجر الذي يتقاضاه 
لايتتاسب وحجم العمل التربوي الذي يقوم به وينجم عن ذلك عدم قدرته على مسايرة متطلبات الحياة

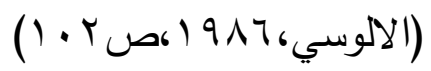

وبينت بعض الدراسات أن الأفراد من ذوي قوة تحمل الثخصية العالي هم الأفراد المقاومون للأمراض

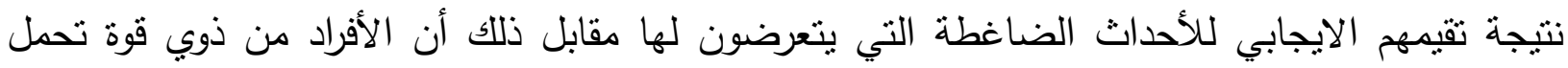

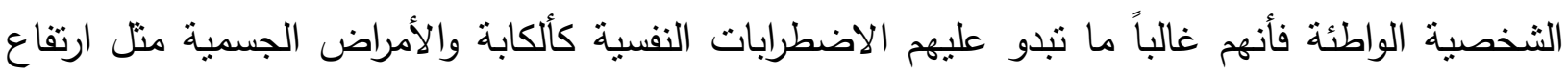

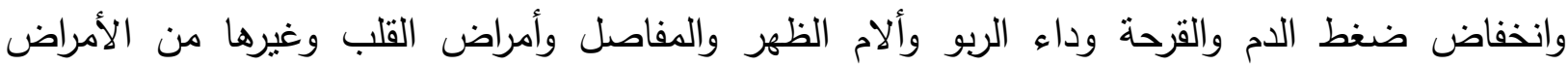

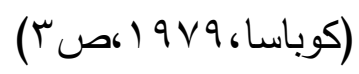

إذ يتعرض المشرف التربوي للضغوط المختلفة وباستمرار يسنطيع أن يعيد توازنه بشكل سريع حال

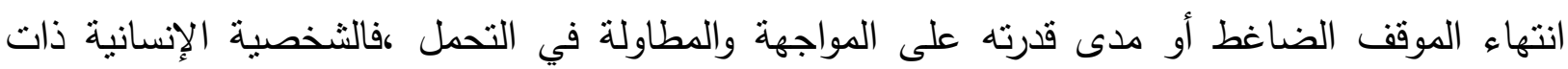

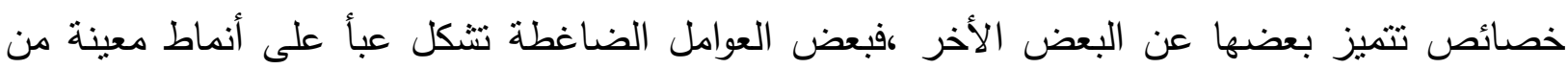

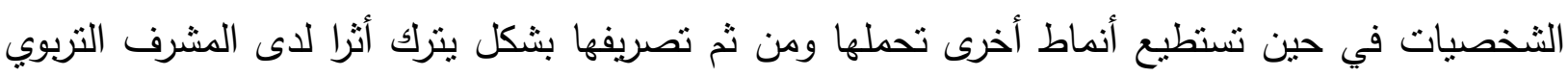

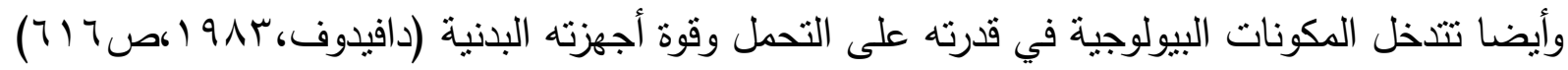

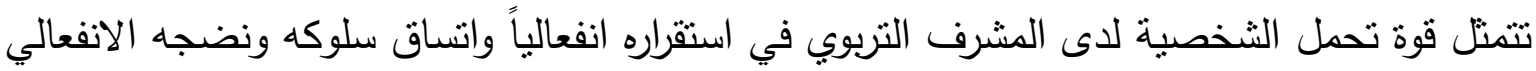
وهدوئه وصبره وكيفية معالجة المشكلات التي تواجهه على أساس من التفكير العلمي وطموحه ودوافعها

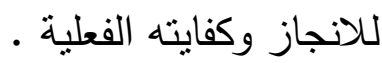
وان من بين خصائص قوة تحمل الثخصية للمشرف التربوي هي الاتجاه الايجابي نحو الذات واحترامها

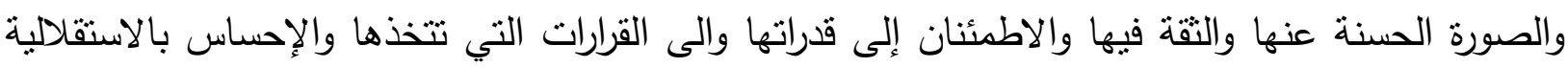
والثتعور بالمسؤولية والرغبة في العمل والتعاون والإسهام في بناء الحضارة الإنسانية ويكون منوافقاً مع الإنى

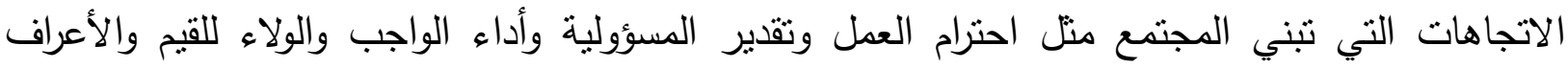
والتقاليد وكذلك بالكيفية التي يستخدم بها الفرد وسائل المقاومة للضغوط للحفاظ على البقاء بصحة جيدة من خلال مواجهته للضغوط، ومن أساليب مقاومة الضغوط تتمثل بقدرة الإنسان على الحد من التأثيرات السلبية

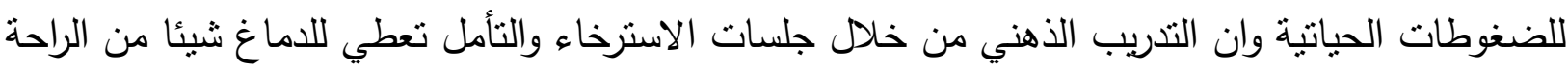
وبالتالي يصبح قادرا على التفكير والثعور بالواقع من اجل تفهمه بهدوء والوصول إلى أفضل الحلول (فاتكاء (0) (1)...06

كما أن الأسس النفسية المتمثلة بمؤشرات الصحة النفسية تعد من أساليب مقاومة الضغوط ويشترط فيها

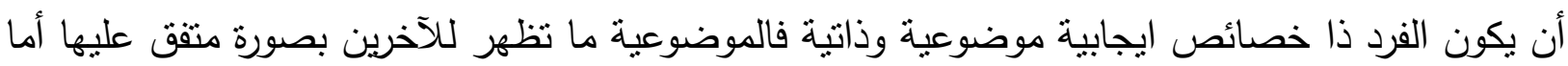

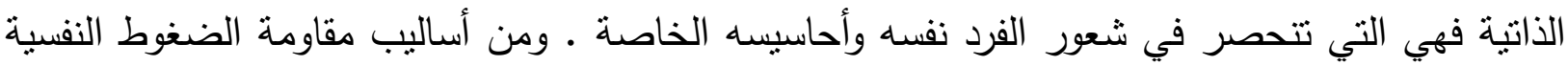

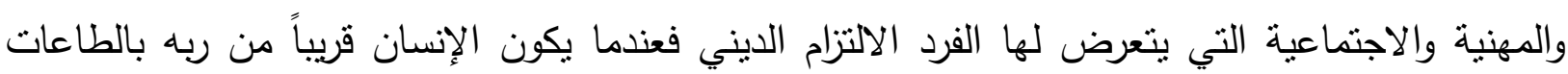

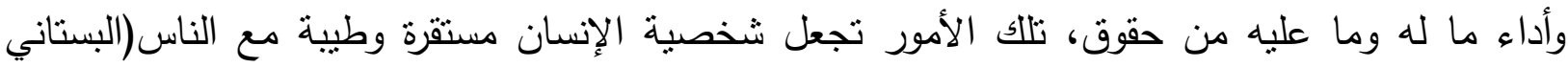

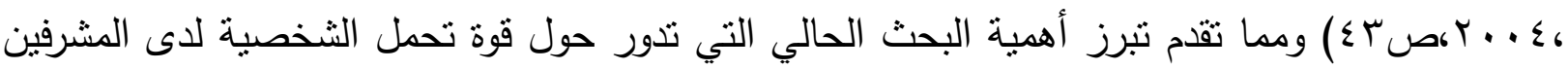


التربوبين في تربية محافظة واسط ودورهم في بناء الوطن وأعداد الأجيال إعدادا علمياً ونفسياً واجتماعياً والارتقاء بالعطلية التربوية وتحقيق أهدافها المنشودة.

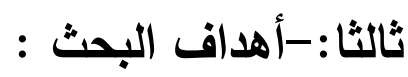

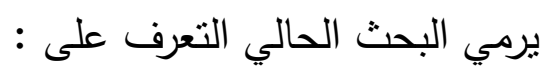

1- مستوى قوة تحمل الثخصية لدى المشرفين التربوبين.

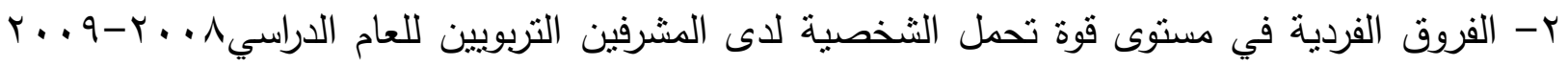
تبعاً لمتغير الجنس( ذكور - الناث)

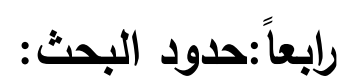

يقتصر أجراء البحث الحالي على المشرفين التربويين في مديرية تربية محافظة واسط خامسا:تحديا المصطلحات : : أنماء

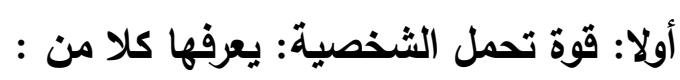
عاقل: بأنها قدرة الفرد على الالتزام والسيطرة والتحدي ولديه أحساساً عالياً بهذه الحالات الثناثة ليكون جريئاً

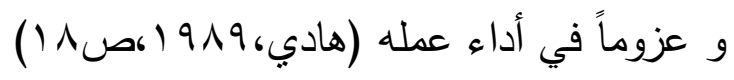
كوياسا : الفرد ذا الثخصية القوية للتحمل هو الذي يمنلاك إحساسا من انه قادر على مواجهة أحداث الحياة الضاغطة التي يتعرض لها وان باستطاعته التعامل معها بشكل يجنبه الإصابة بالاضطرابات النفسية

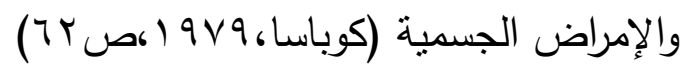
تعريف الباحث هو الفرد ذا الثخصية القوية للتحمل بأنه يمتلك إحساسا في مجالات الالتزام والتحدي والسيطرة والقدرة على مقاومة الضغوط النفسية والمهنية والاجتماعية التي يواجهها والسيطرة عليها. ثانيا:-الأشراف التريوي:يعرفه كل من: برجز :بأنه تتسيق وتوجيه نمو المعلمين مما يضمن توجيه كل طفل للمشاركة الفاعلة الذكية في المجتمع

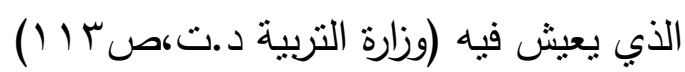
الفونسو:بأنه عبارة عن سلوك مصمم يهدف إلى التأثثر المباشر والفعال في سلوك المعلمين بأسلوب يسهل

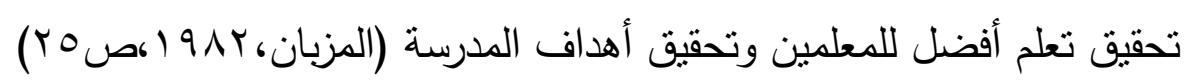
الباحث يعرف الإثراف التربوي: هو عملية تربوية متكاملة تعني بالأهداف والمناهج وأساليب التعليم والتوجيه

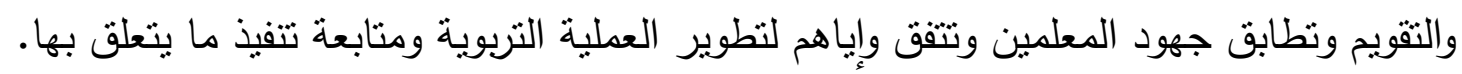
الفصل الثاني الإطار النظري

أولا:قوة تحمل الثخصية نظرية كوياسا 
طرحت هذا المفهوم في الثخصية كوباسا في 9 واويرى الباحثون أن المفهوم هو الأكثر علاقة

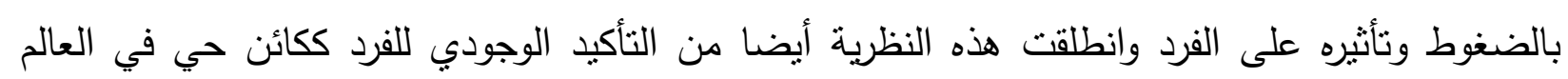

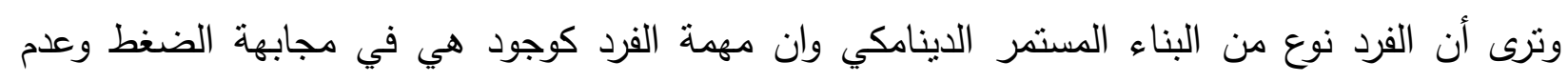

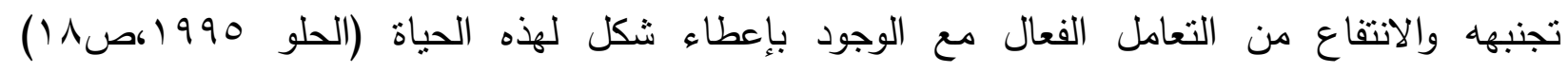

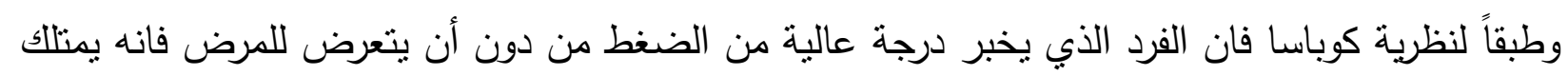

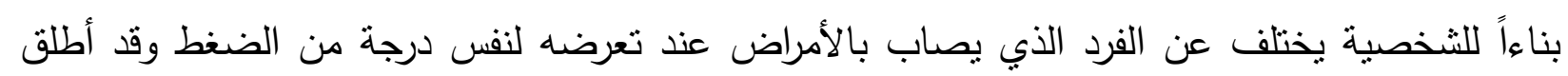

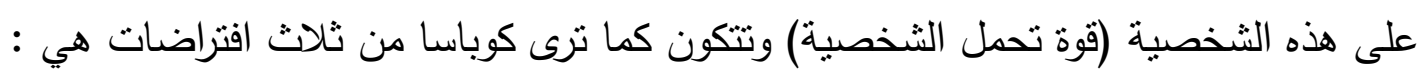

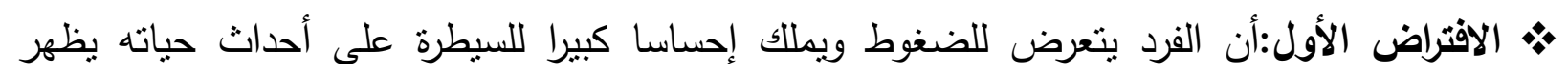
بصحة أفضل من أولئك الذين يشعرون بعدم امتلاكهم القوة والسيطرة على مثل الأحداث.

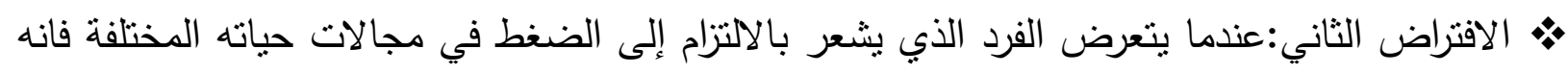

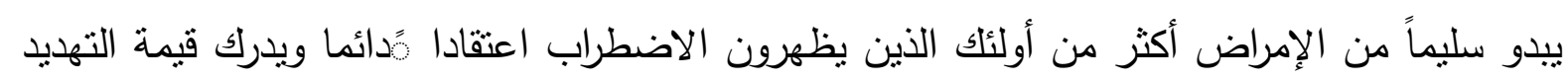
بدرجة اقل مما هو عليه في الواقع لدى تعرضه لأحداث الحياة الضاغطة ولذلك فألكان مواجهته للايئة

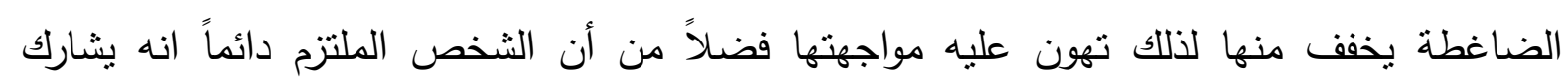

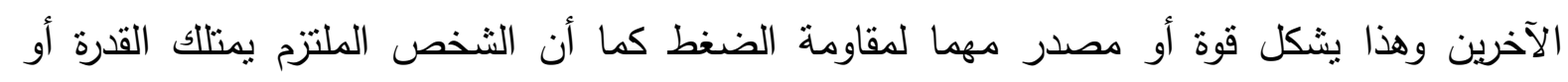

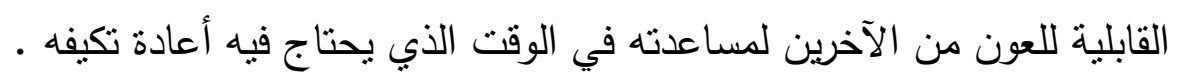

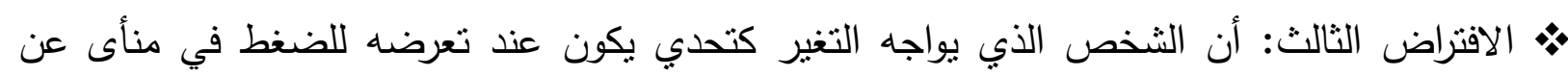

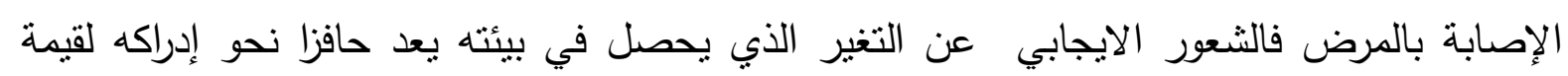

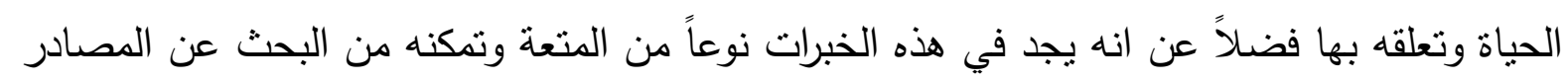

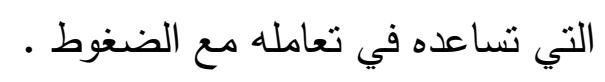

وقد اتجهت الكثير من البحوث لدراسة هذا المتغير وعلاقته بالإصابة بالأمراض والصحة النفسية

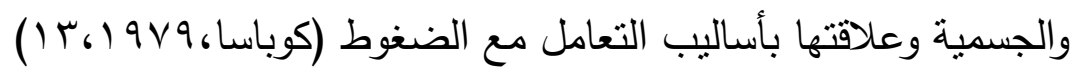

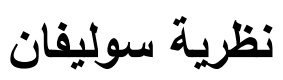

تعد نظرية (هاري ستاك سوليفان) من النظريات التفاعلية فهو يتحدث عن كيفية نمو الثخصية منذ

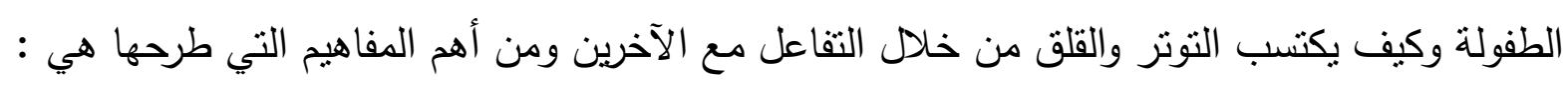

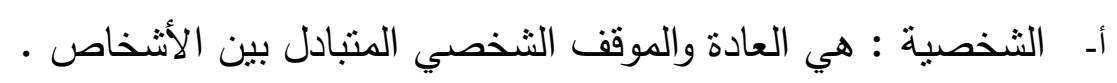

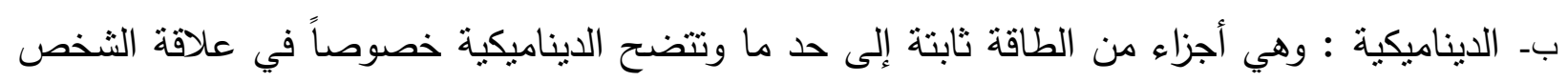

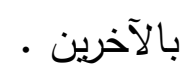

ج- الذات :وهي من أساليب سلوكية يكتسبها الفرد تجعله آمنا فوجود الذات الآمنة المتوافقة تعد بمثابة

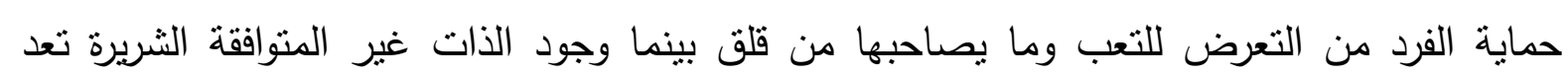

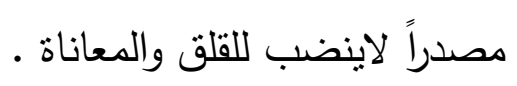


دــ التوتز والقلق:يرى سوليفان وجود توتر داخلي محكوم بحاجات الفرد وإثباع التوتر وهناك نوع من النوتر محكوم بالقلق نتيجة المخاوف أو أخطار واقعية أو خيالية مما ينعكس على داخلى علاقة الفرد بالآخرين

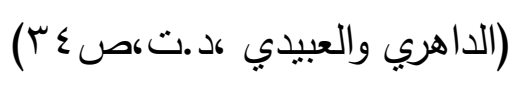

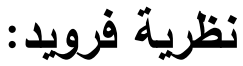

وهي تتكون من تركيبات رئيسة في بنية الثخصية وهي:ألهو، الأنا ،الأنا العليا فألهو: النظام الأصلي

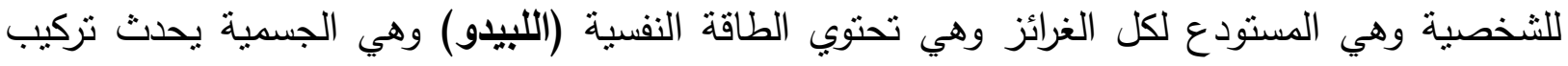

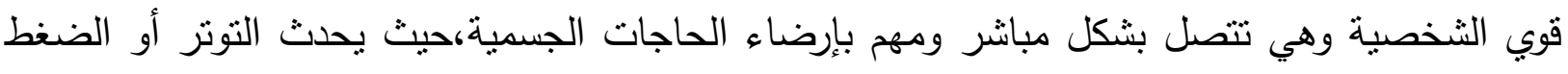

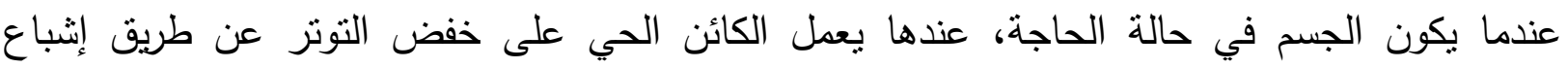

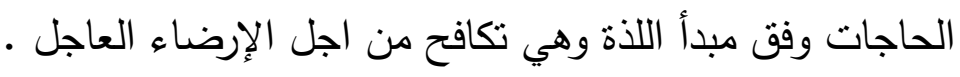

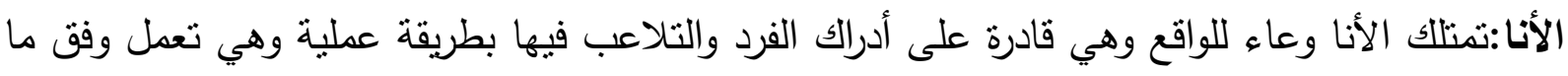

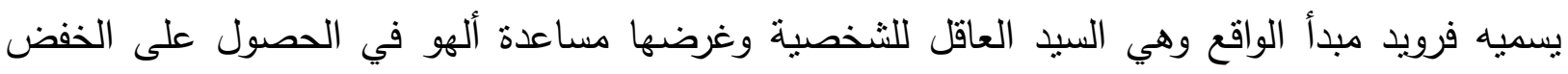
الضروري للتوتز وهي تقرر الوقت والأسلوب للإنشباع بشكل مناسب.

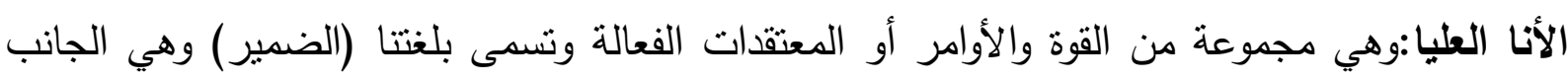

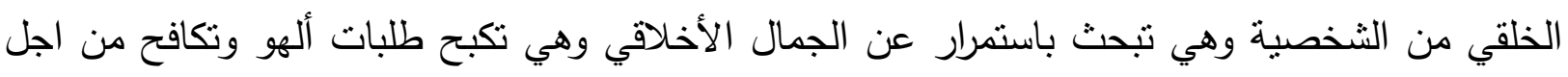

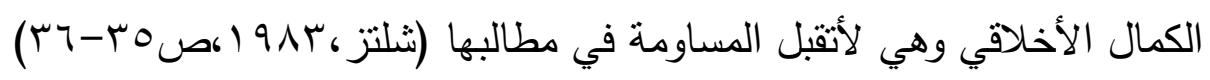

\section{نظرية ادلر:}

الثيء المميز لنظرية ادلر هو فكرته عن ما بسمى بالذات الخلاقة وهي نظاماً شخصياً وذانياً للغاية

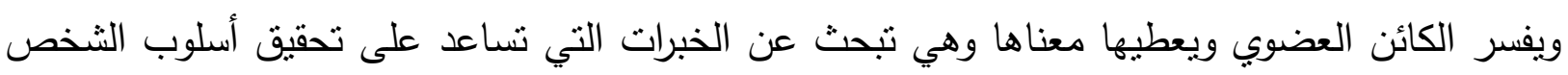

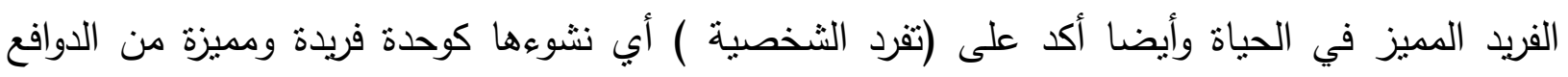

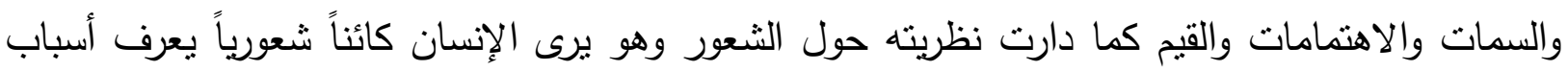

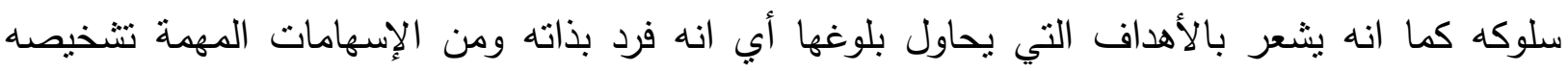

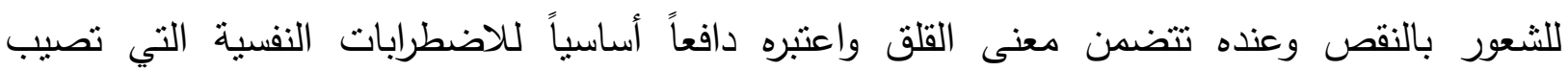

$$
\begin{aligned}
& \text { الثخصية (الهيتي،919 (،صل } 1910 \\
& \text { ثنانيا:الإثراف التزبوي } \\
& \text { المفهوم القديم للأشراف التريوي: }
\end{aligned}
$$

أن المتتبع لتاريخ الإثراف التنربوي يجد انه ابتدأ أول الأمر على مستوى التقتش الذي يعني نلإنك

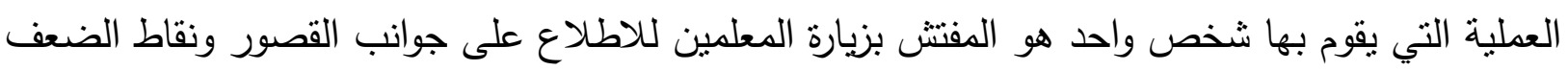

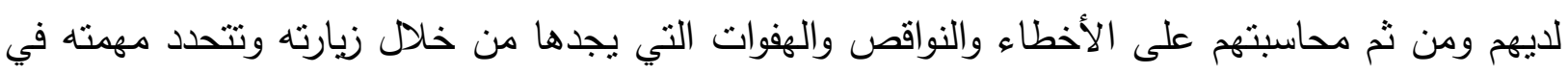

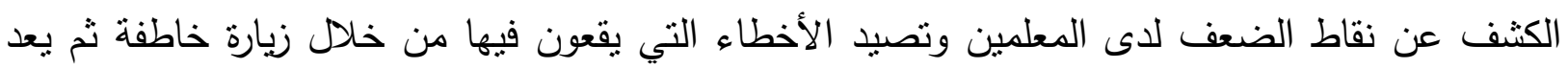

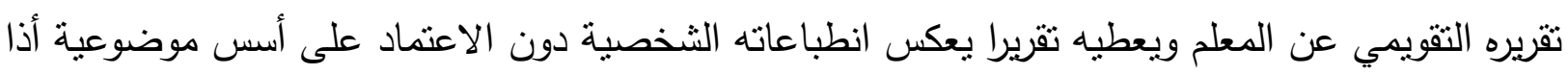


كان سلبياً تأثيره على المعلم من حيث استمراره بالععل أو بقائه في مدرسته ذلك أن النقل إلى مدرسة بعيدة أو نائية من أكثر الإجراءات التي كان بستخدمها المفتشون إزاء المعلمين الذين لايرضون عنهم

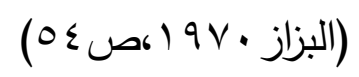

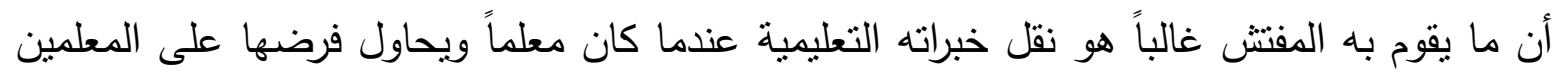

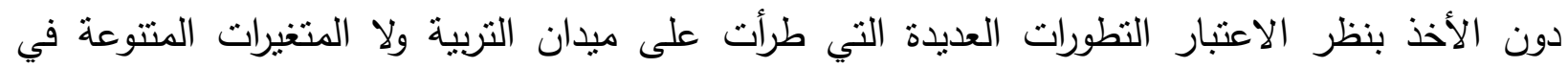

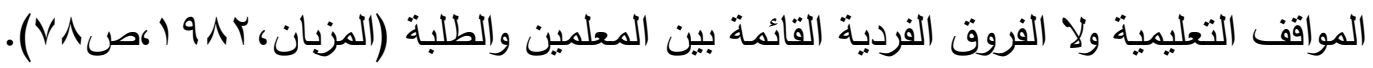

\section{المفهوم الحديث للإثراف التريوي:}

أن التطورات الكبيرة التي تحققت في مجال الفكر التربوي وما تضمنه من فلسفة وأهداف تربوية

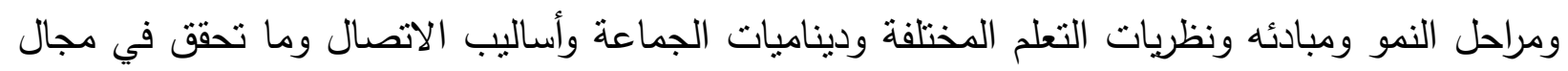

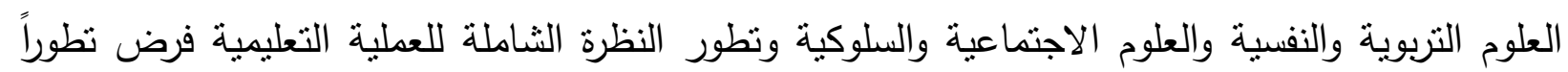

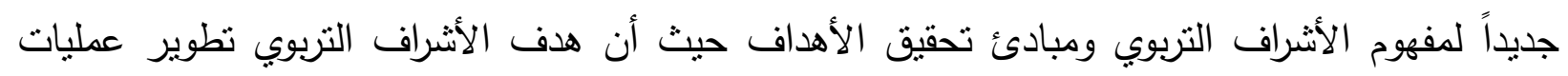

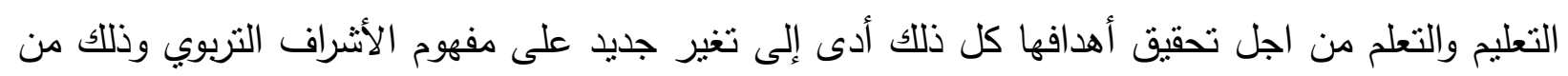

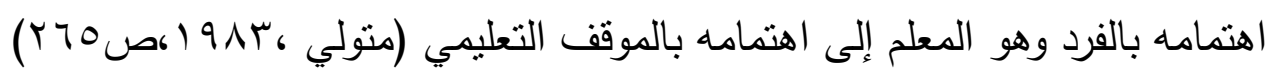

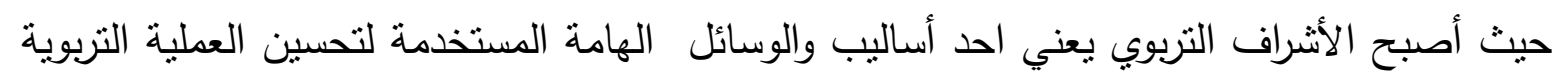

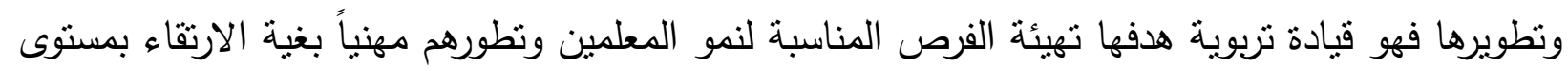

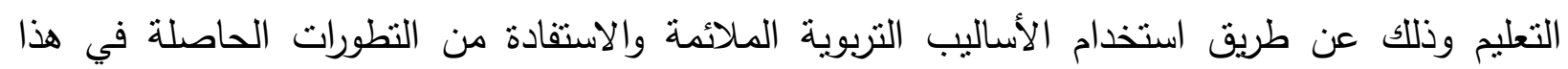
المجال .أن الأشراف التربوي بعني تتسيق وتوجيه نمو المعلمين بما يضمن توجيه كل طفل للمشاركة الفاعلة

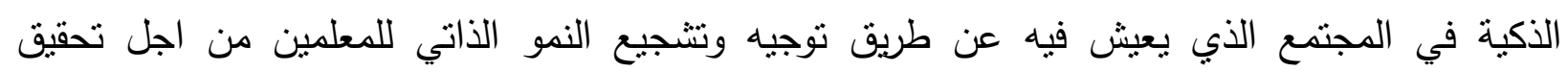

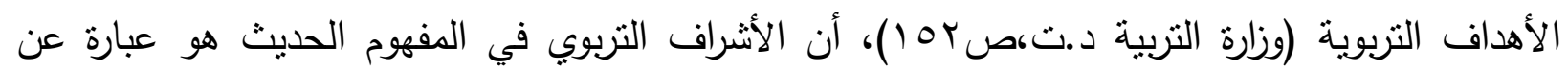

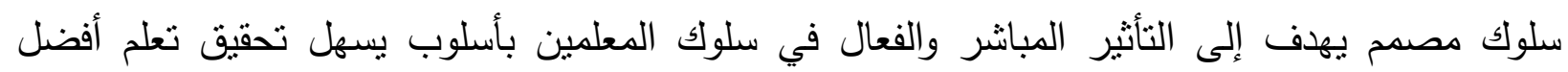

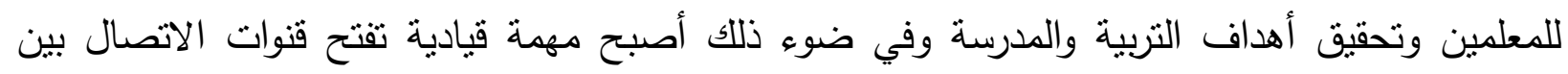

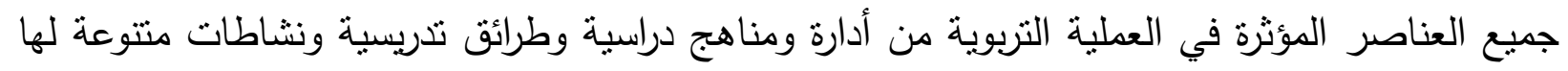
علاقة بعملية التعلم. الاراسات السابقة :

( ) (دراسة روز 19 19 الموسومة (الأمراض وعلاقتها بقوة تحمل الثخصية لدى النساء )

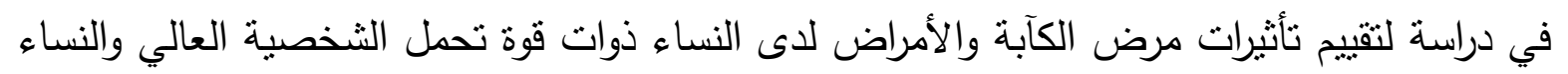

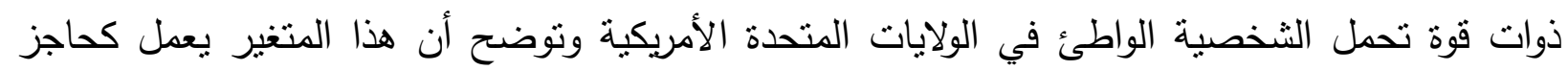

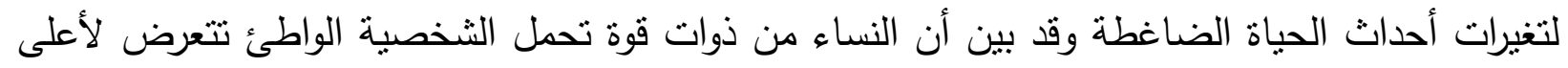

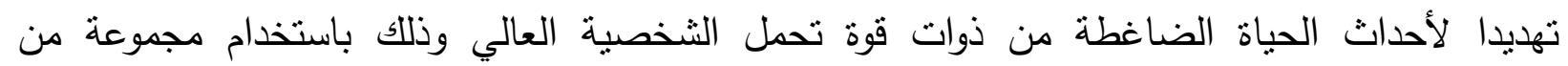

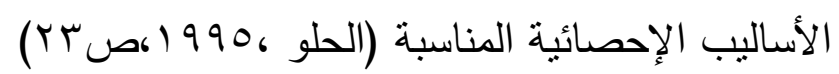


ب)دراسة كانلن 1919 الموسومة (دراسة قوة تحمل الثخصية وعلاقتها بالإسناد الاجتماعي )

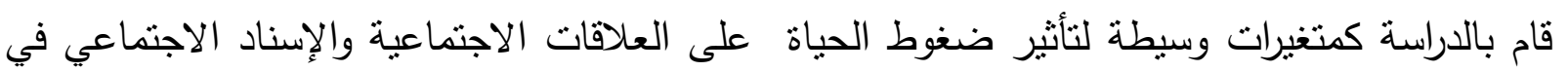

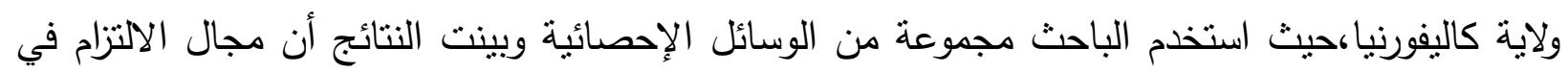

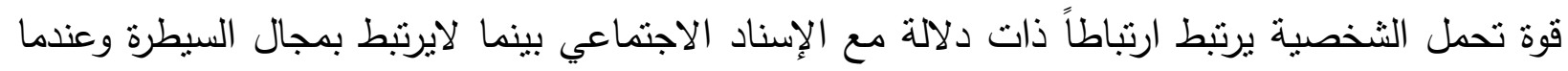

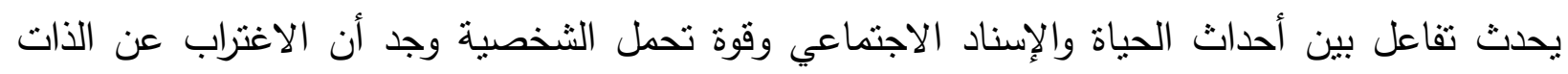

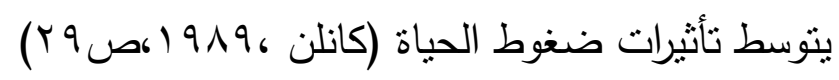

r)دراسة بثينة منصور الحلو 1990 (قوة تحمل الثخصية لاى طلبة الجامعة)

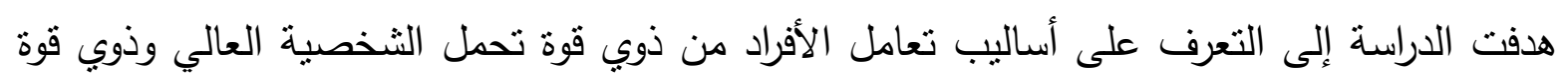

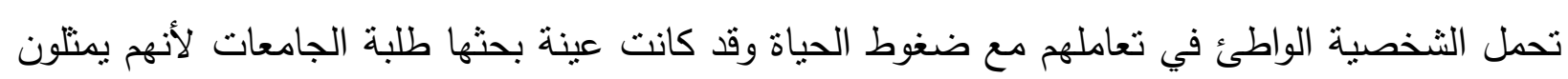

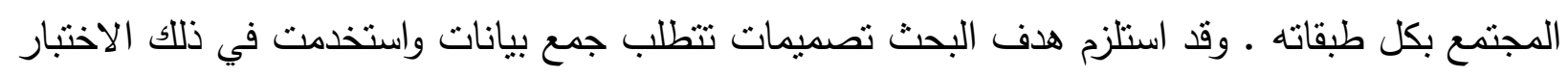

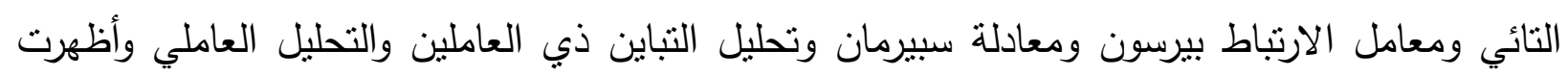

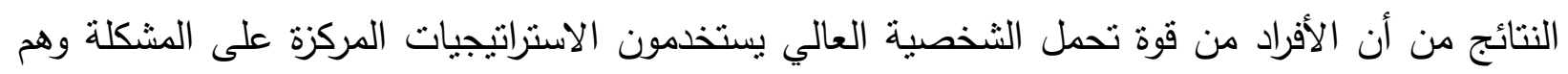

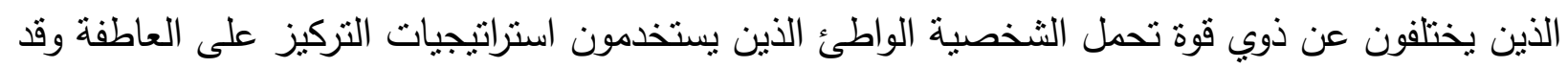

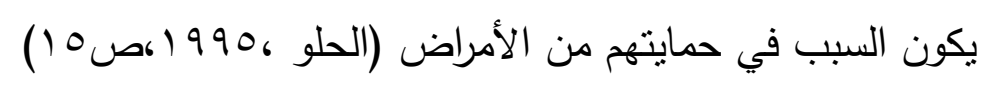

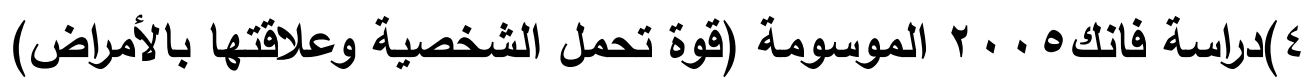

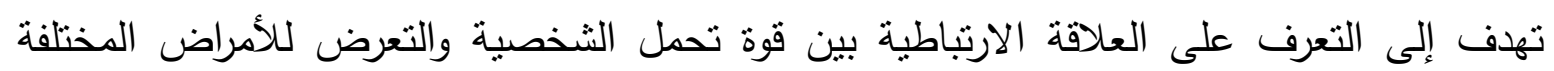

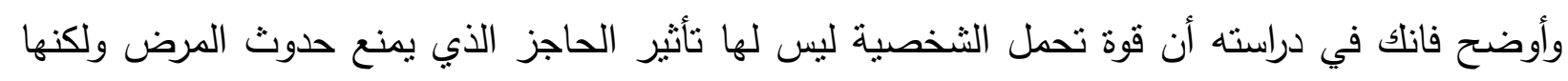

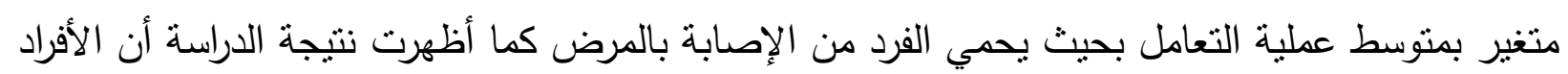

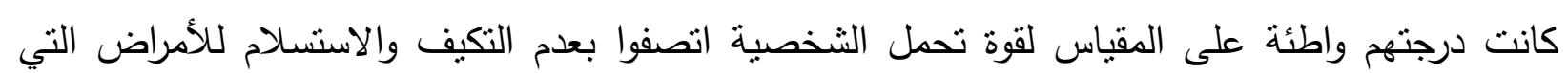

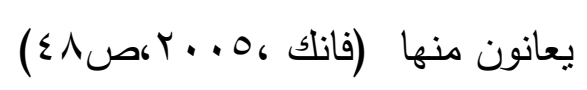

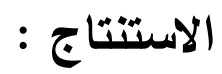

من خلال متابعة الدراسات السابقة بستتتج الباحث ماياتي :

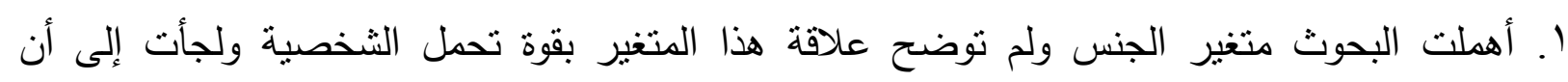

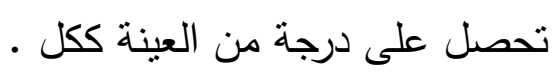

r. اتقفت الدراسات على أن متغير قوة تحمل الثخصية يجعل الفرد متكيفاً من خلال تقديم الاستجابة

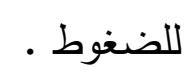

r. انفقت اغلب الدراسات على أن قوة تحمل الثخصية هي ليست مجالاً واحداً وإنما ثلاث مجالات فسلجية

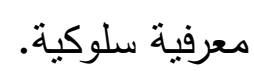

؛. عمدت الدراسات إلى استخدام التحليل العاملي لتحقيق صدق الدفهوم كما عدد الى استخام أعادة

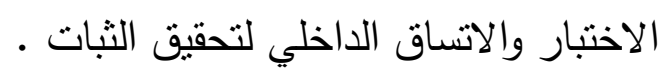


๑. استخدمت اغلب الدراسات مقياس هولمز لقياس ضغوط للحياة . 7. كما اتفقت نتائج البحوث على أن متغير قوة تحمل الثخصية يرتبط ارتباطا بالأفراد ذوي التكيف السليم وان قوة تحمل الثخصية الواطئ تظهر عليهم الأمراض باستمرار سواء كانت نفسية أو جسمية. V. أجريت الدراسات التي جاءت بعد كوباسا أما لإعادة تحديد مجالات قوة تحمل الثخصية أو لدراسة علاقة هذا المتغير بالصحة النفسية والجسمية ولحداثة هذا المتغير لم تجر دراسات عليه في الحضارة العربية باستثناء دراسة بثينة منصور الحلو. الفصل الثالث

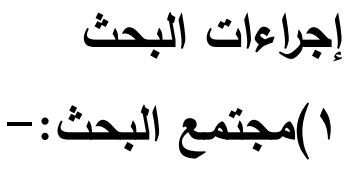

يتكون مجتمع البحث الحالي من (79 ) مشرفاً تربوياً يتوزعون على أقضية ونواحي محافظة واسط

وللاختصاصات كافة للعام الدراسي ^ . . r-9 . . rم والجدول ( (1) يوضح ذلك جدول(1)

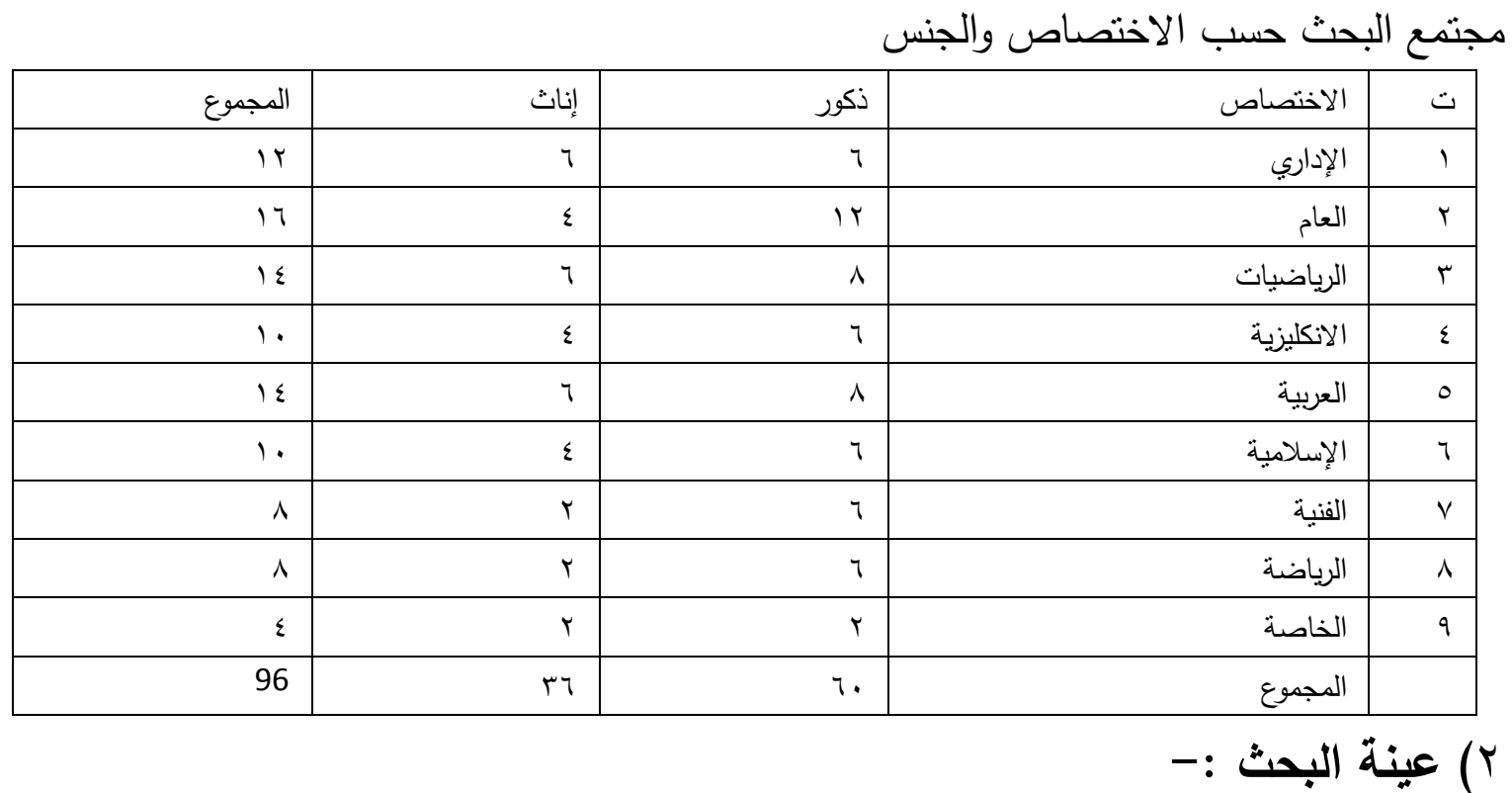

قام الباحث بسحب عينة عشوائية بلغت ( • 7) مشرفاً تربوياً يتوزعون على الاختصاصات التالية (الإداري ،العام ،الرياضيات ،الانكليزية ،العربية ،الإسلامية ،الفنية ،التربية الرياضية التربية الخاصة ) والجدول(r) يوضتح ذلك جدول (r) عينة البحث موزعة بحسب الاختصاص والجنس

\begin{tabular}{|c|c|c|c|c|}
\hline المجموع & إناث & ذكور & الاختصاص & ت \\
\hline 7 & $r$ & r & الإداري & 1 \\
\hline ir & $r$ & 9 & العام & r \\
\hline$\wedge$ & $\varepsilon$ & $\varepsilon$ & الرياضيات & $r$ \\
\hline 。 & r & $r$ & الانكليزية & $\varepsilon$ \\
\hline
\end{tabular}




\begin{tabular}{|c|c|c|c|c|}
\hline$\wedge$ & $\varepsilon$ & $\varepsilon$ & العربية & 0 \\
\hline V & $r$ & 0 & الإسلامية & 7 \\
\hline 0 & r & $r$ & الفنية & v \\
\hline 0 & $r$ & $r$ & الرياضة & $\wedge$ \\
\hline$\varepsilon$ & $r$ & $r$ & الخاصة & 9 \\
\hline 7. & $r \leq$ & דr & المجموع & \\
\hline
\end{tabular}

ثالثا: أدوات البحث:-

بما أن البحث الحالي يستهدف التعرف على مستوى قوة تحمل الثخصية لدى المشرفين التربويين لذلك تطلب توافر مقياس يتمتع بخصائص سيكومترية لتحقيق أهداف البحث . وبعد اطلاع الباحث على الأدبيات والدراسات السابقة ذات الصلة تقرر أعداد أداة تلائم مشكلة البحث والعينة إذ انه لا توجد أداة لذلك وعلى هذا الأساس قام الباحث بتوزيع استبانه استطلاعية لعينة مكونة من (Y. ) مشرف ومشرفة اختيروا عشوائيا وطلب منهم ذكر ما بأني:ا-أهم المشاكل والضغوط التي تواجههم في حياتهم العامة وعملهم خاصة . r-أهم الأساليب التي يستخدمونها لمواجهة هذه المشاكل والتعامل معها والتكيف لها . وبعد مراجعة الأدبيات والدراسات السابقة ذات الصلة تم الحصول على عدد من الفقرات وبذلك تكون المقياس بصورته الأولية من (\&V) فقرة. أعداد تعليماث المقياس: أن تعليمات المقياس هي بمثابة الدليل في الإجابة على فقراته لذا روعي عند أعداد التعليمات أن تكون غير طويلة ولزيادة الوضوح وضع الباحث تعليمات توضح كيفية الإجابة على فقرات المقياس ملحق(ع) لحث المستجيب على أعطاء إجابات أكثر صراحة ودقة .

\section{تصحيح المقياس :-}

لحساب الدرجة التي يحصل عليها المستجيب من خلال إجابته على فقرات المقياس وضعت الدرجات المناسبة لكل الفقرات موزعة على بدائل المقياس الأربعة التي تم تحديدها والجدول (ب) يوضح ذلك . جدول(r)

وزن الفقرات ويدائل الإجابة عنها

\begin{tabular}{|c|c|c|c|c|}
\hline ارفض بشدة & أوفق قليلا & أوفق أحيانا & أوافق تماما & بدائل الإجابة \\
\hline 1 & r & $r$ & $\varepsilon$ & وزن الفقرة \\
\hline
\end{tabular}

الخصائص السيكومترية للمقياس :-

الصدق : (الصد

يعد الصدق من الخصائص المهمة في الاختبارات فالاختبار الصادق هو ذلك الاختبار القادر على

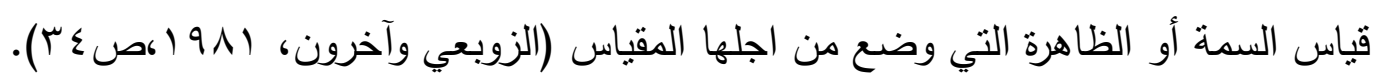


بعد أن تمت صياغة فقرات المقياس وتعليماته وبدائل الإجابة بصيغتها الأولية تم عرض المقياس على :ملى

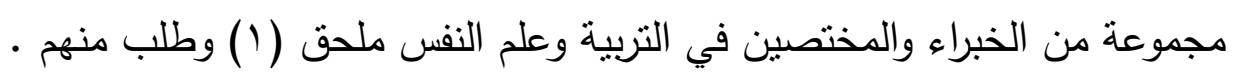
1 ا-الحكم على مدى صلاحية الفقرات لقياس ما وضعت لأجله ومدى ملائمنها .

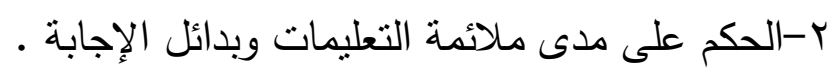

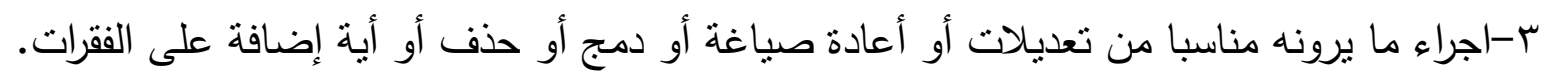

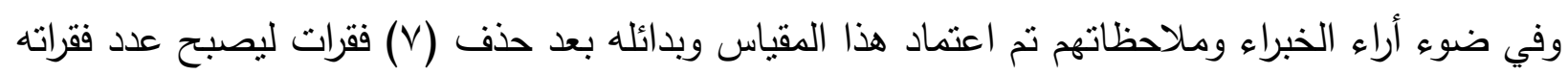

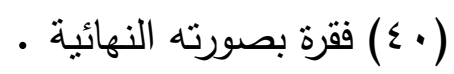
ثبات المقياس يقصد بالثبات هو انساق درجات الاختبار ودقة نتائجه وتحريرها من ناثيرات الصدفة عندما يطبق على

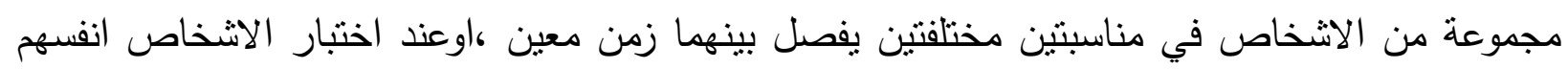

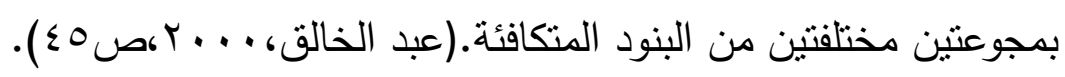
أبريقة أعادة الاختبار

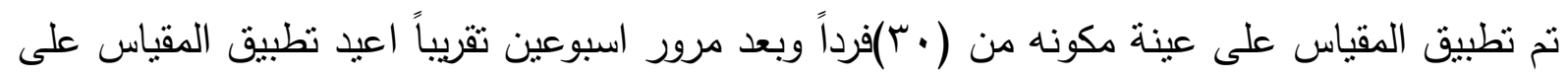

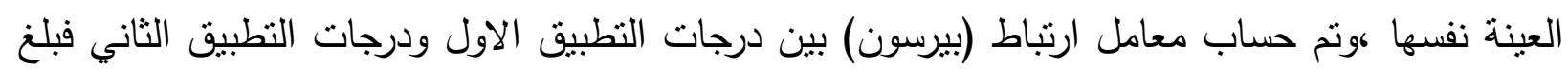

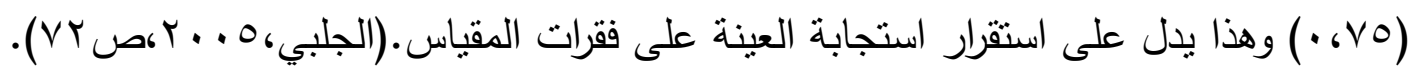
r- طريقة التجزئة النصفية تم سحب (•r) استمارة عشوائياً ومن ثم تقسيم فقرات المقياس الى نصفين متساويين فردية وزوجية ، وبعد

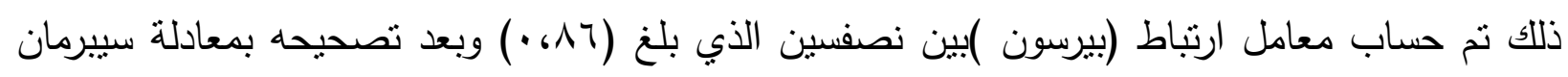

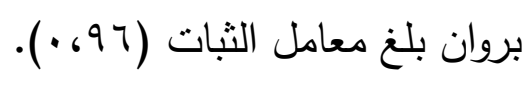

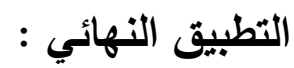
وبعد أن تم أكمال إجراءات بناء المقياس تم تطبيقه بصفته النهائية على عينة البحث وكان عددها

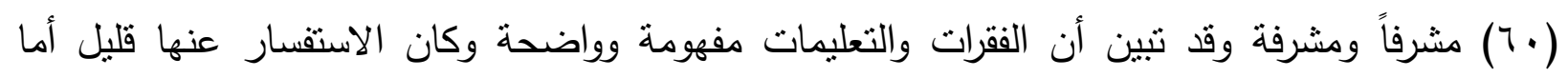

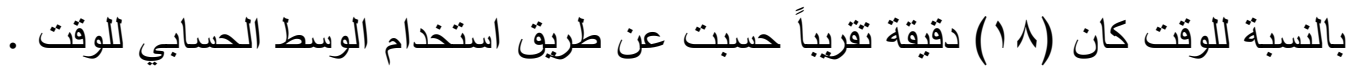
الوسائل الإحصائية : استخدم الباحث مجموعة من الوسائل الإحصائية لمعالجة البيانات بغية التحقق من أهداف البحث وهي: * معامل ارتباط بيرسون

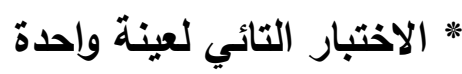
* الاختبار التائي لعينتين مستقلتين الفصل الرابع 
يتضمن هذا الفصل عرضاً للنتائج وتفسيرها في ضوء أهداف البحث وكما يلي:

الهدف الأول:التعرف على مستوى قوة تحمل الثخصية لاى المشرفين التربوبين لغرض تحديد مستوى قوة تحمل الثخصية لدى أفراد عينة البحث نم حساب المتوسط الحسابي للارجات الكلبة للمقياس ولجميع أفراد

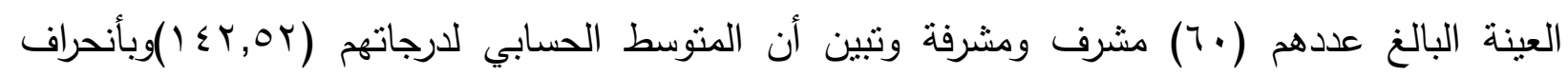

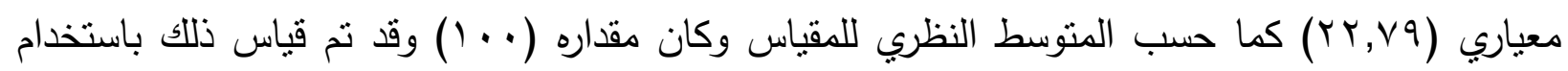

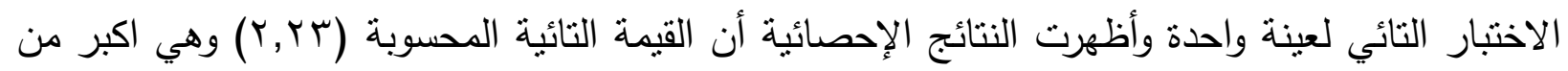

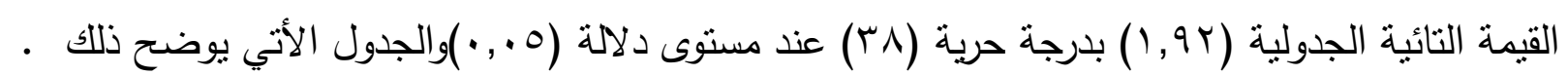

جدول(ع)

المتوسط الحسابي والنظري والقيمة التائية

\begin{tabular}{|c|c|c|c|c|c|c|}
\hline \multirow{2}{*}{ مالد الدنة } & \multicolumn{2}{|r|}{ القيمة التائية } & \multirow[t]{2}{*}{ المتوسط النظري } & \multirow{2}{*}{ الالنحراف } & \multirow[t]{2}{*}{ المتوسط الحسابي } & \multirow[t]{2}{*}{ أفراد } \\
\hline & الجدولية & المحسوبة & & & & \\
\hline دال & $1,9 r$ & T,YT & $1 \ldots$ & rr,vq & $1 \leqslant r, O r$ & 7. \\
\hline
\end{tabular}

ويتضح من الجدول أعلاه أن عينة البحث بالنسبة للمشرفين التربوبين الذكور والإناث يتمتعون بقوة تحمل الثخصية وتقسير هذه النتيجة بان المشرف التربوي كائن اجتماعي فئنة فعال يؤثر ويتأثر بالمعايير البيئية والحضارية السائدة في المجتمع فهو يعيش في بيئة متفاعلاً معها بأخذ منها ويعطيها.

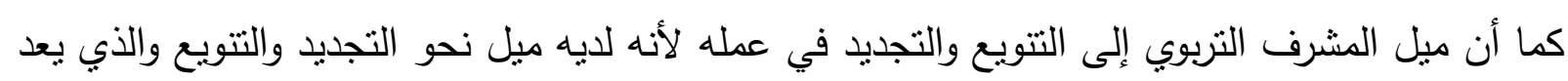

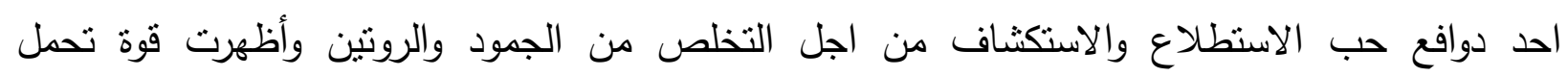

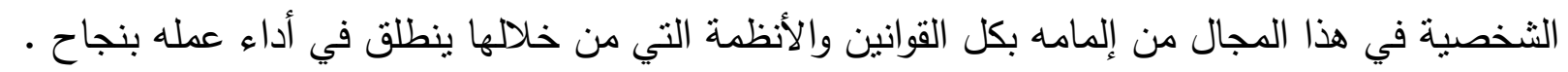
الهلف الثاني: التعرف على الفروق الفردية في مسنوى قوة تحمل الثخصية حسب متغير الجنس (ذكور إناث).

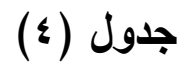

نتائج الاختبار التائي لعينتين مستقلتين

\begin{tabular}{|c|c|c|c|c|c|c|c|}
\hline هـ., مستوى الدلالة & التدائية & التائية & النظري & الانحراف & الحسابي & العينة $\quad$ أفراد & الجنس \\
\hline دال & 1,17 & $T, Y T$ & $1 \ldots$ & 14,19 & 111 & $\varepsilon$. & ذكور \\
\hline دال & $1, \times 7$ & I, & $1 \ldots$ & 11,11 & 97 & $r$. & إناث \\
\hline
\end{tabular}

والجدول (0) يوضح أن هناك فروقاً في قوة تحمل الثخصية بن الذكور والإناث حيث دلت النتائج

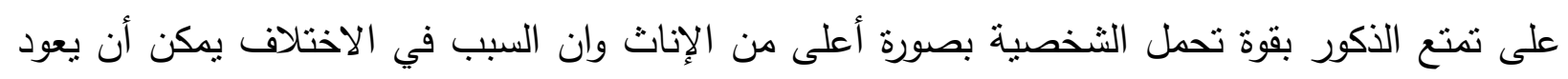


إلى التتشئة الاجتماعية التي تحدد الدور الذي يلعبه كلا من الذكر والأنثى في المجتمع فكما هو واضح أن

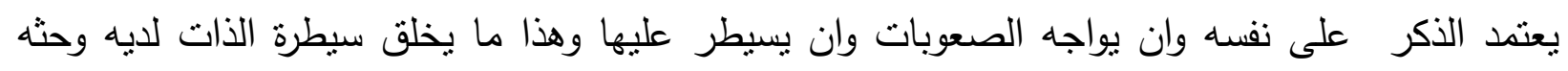

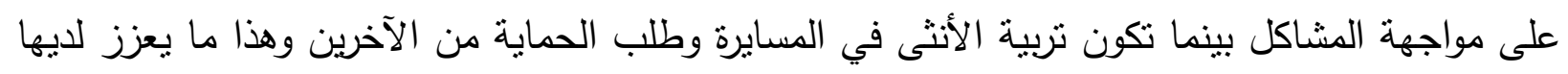
فكرة الضعف وأنها غير قادرة على مواجهة الحياة .

وفي ديننا تأكيد على ذلك من خلال الآيات القرآنية (وليس الذكر كالأنثى ) (الرجال قوامون على على النساء بما

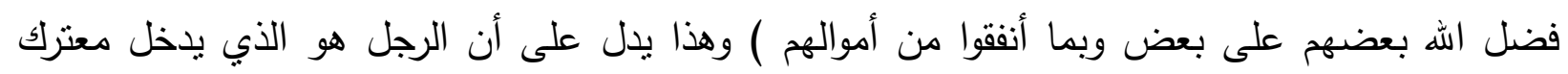
الحياة ويواجه كل ضغنوطها ومشاكلها.

التوصيات

وفي ضوء نتائج البحث يمكن أن يوصي الباحث بما يلي :

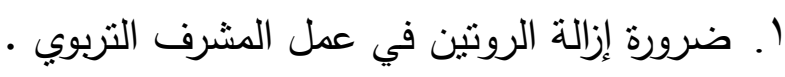

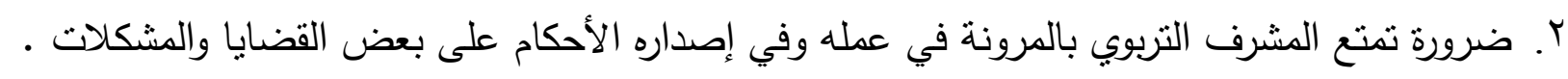

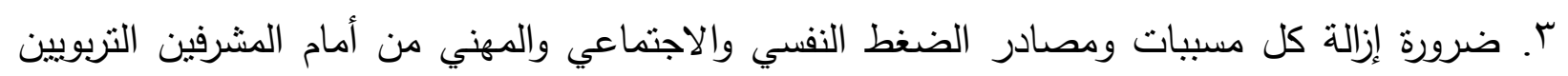

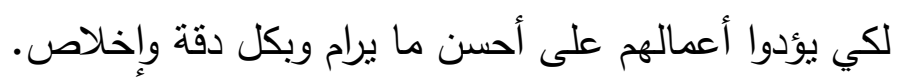

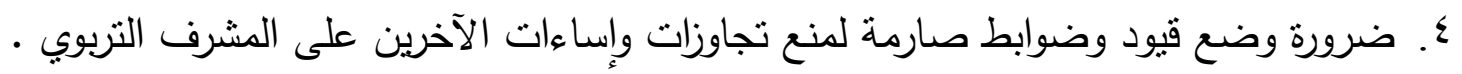

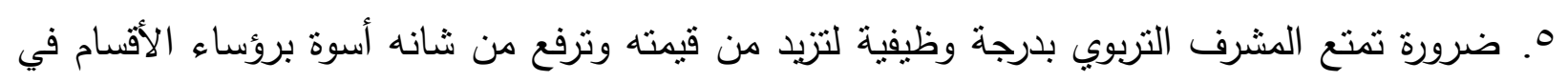

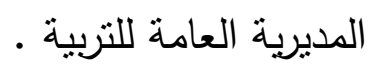

T. ضرورة صرف مخصصات نقل للمشرف التربوي بسبب تتقله المستمر بين المدارس المختلفة والمتباعدة

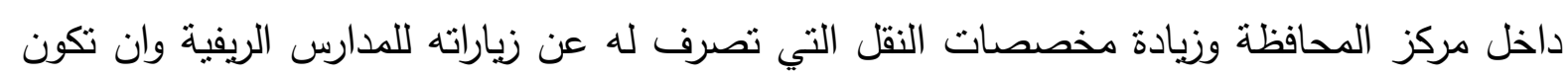

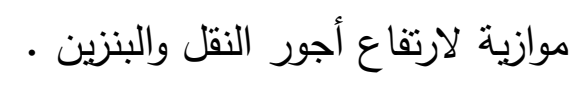

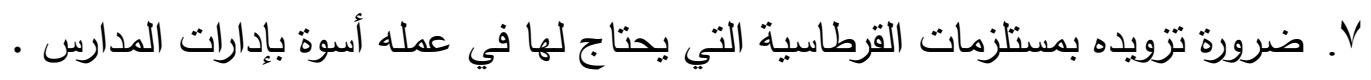

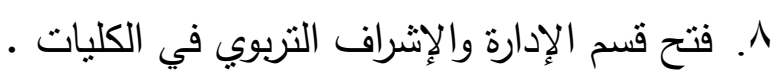

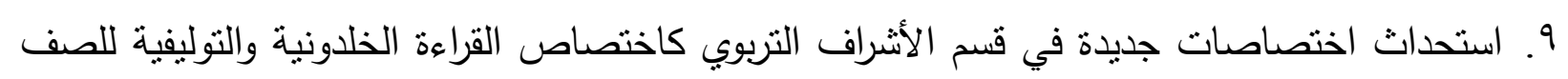
الأول الابتدائي واختصاص للاجتماعيات وأخر للعلوم والتربية الصحية الخ.

رابعا:(المقترحات

استكمالا للاراسة الحالية يقترح الباحث اجراء الدراسات المستقلية الآثية :

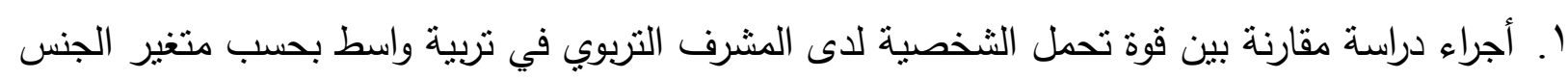

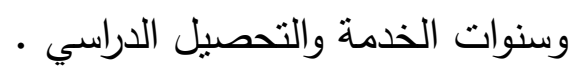
ץ. إجراء دراسة مقارنة بين قوة تحمل الثخصية لدى المشرف التربوي للمرحلة الابتدائية والمشرف

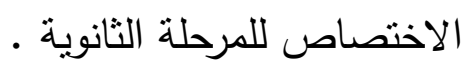
r. إجراء دراسة عن استراتيجيات مواجهة الضغوط النفسية لاى المشرفين التربويين . 
ع. إجراء دراسة عن استراتيجيات تعزيز قوة التحمل لدى المشرف التربوي •

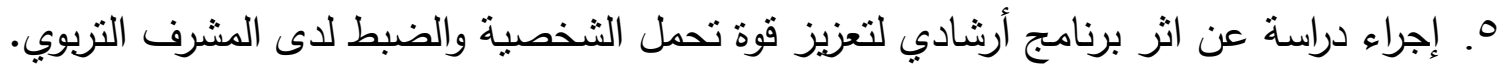

قائمة المصادر

القران الكريم

الالوسي ،جمال الدين :الأسس النفسية لمعاملة التلميذ وأثزها في ثقته بنفسه، وزارة التربية المديرية العامة للتخطيط التربوي

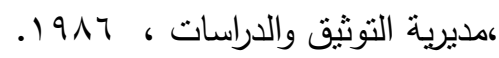

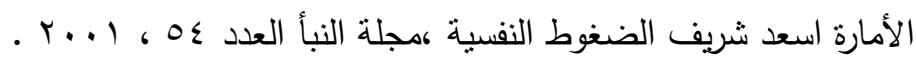

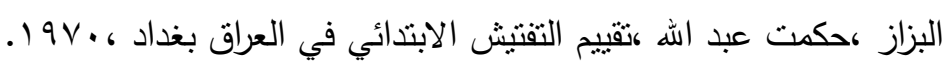

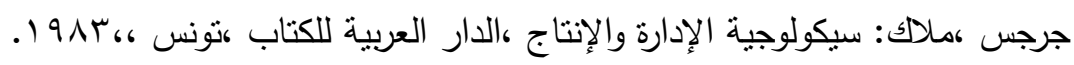
الجسماني،عبد علي: توجيه المناهج لتعزيز شخصبة الطالب في مسألة الثقة بالنفس واتخاذ القرارات ،وزارة التربية ،

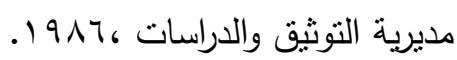
الحلو ،بثينة منصور :قوة تحمل الثخصية وأساليب التعامل مع ضغوط الحياة رسالة دكتوراه، كلية الآداب ،جامعة بغداد 1990 190

الحمداني ، موفق: توجيه المناهج وطرائق التدريس لتعزيز شخصية الطالب في مسألة اتخاذ القرار مديرية التوثيق

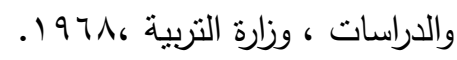

دافيدوف ،لندال ،مدخل علم النفس كترجمة سيد الطواب وآخرون مكتبة الثريرة ، 919 ا ـ الداهري صالح ومحمد العبيدي: الثخصية والصحة النفسية،وزارة التعليم العالي بغداد، 9 19

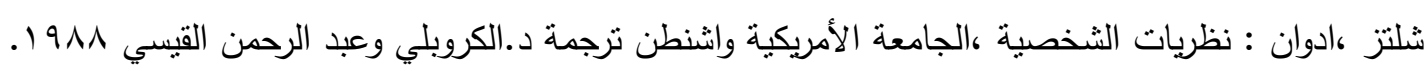
فانك ،ك.ل، قوة تحمل الثخصبة وعلاقتها بالأمراض ،ملخص بحث منشور باللغة العربية ، 0 . . ب. كانلن ، العلاقة بين قوة تحمل الشخصية والإسناد الاجتماعي ،ملخص بحث منشور باللغة العربية في الانترنيت 9 19 ـ. متولي ، مصطفى : الإشراف الفني في التعليم ،دراسة مقارنة ،دار المطبوعات الجديدة،الإسكندرية، سمو ا. المزبان ،سليمان يوسف بعض الأبعاد المنهجية في مسالة زرع الثقة بالنفس وزارة التربية،المديرية العامة للتخطبط التربوي

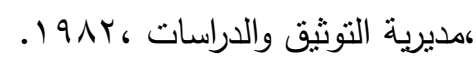
موسى عبد الهادي علي :المدخل إلى علم النفس ،مكتبة الخانجي القاهرة ، 9 V ـ . نايت ،ركسن مارجيت، المدخل إلى علم النفس ،بغداد ،1901 190

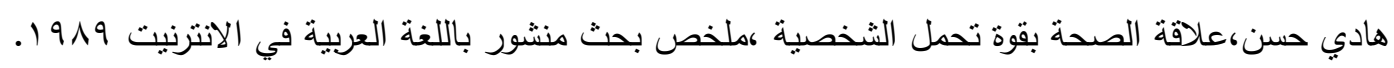
الهيتي ،مصطفى عبد السلام :عالم الشخصية ، مكتبة الثرق الجديد، بغداد 910 . وزارة التربية ،الإدارة والإثراف للصف الثاني معاهد أعداد المعلمين المرحلة الرابعة كلية التربية ،قسم العلوم التربوية والنفسية كد.ت. وزارة التربية ،دليل المشرف التربوي ، و1901.

ملحق (1)

السادة الخبراء الذين استعان بهم الباحث

\begin{tabular}{|c|c|}
\hline مكان العمل & أسماء الخبراء \\
\hline
\end{tabular}




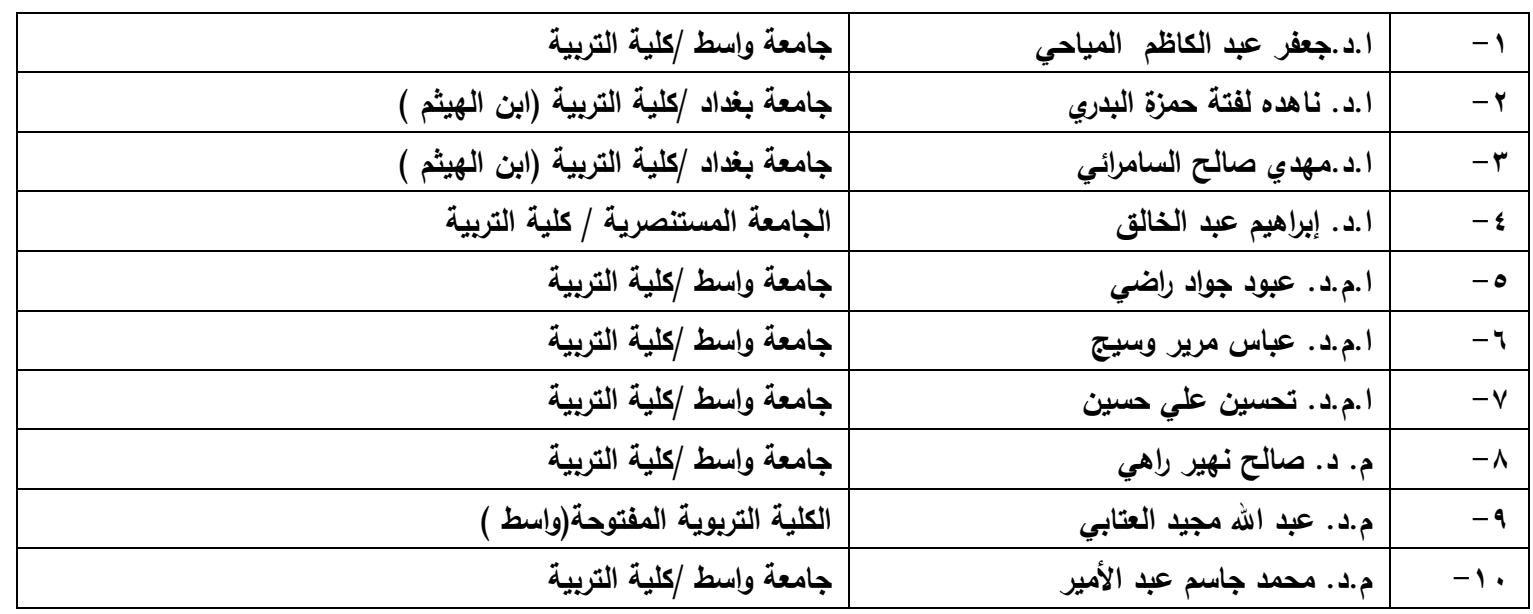

ملحق (r)

جامعة واسط

كلية التربية

قسم العلوم التزيوية والنفسية

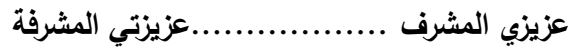

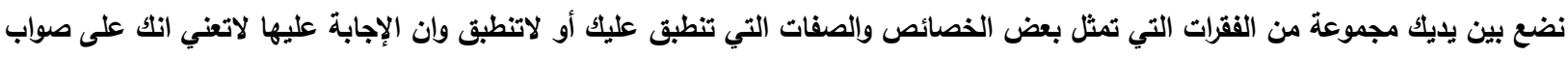

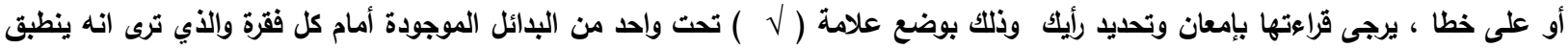

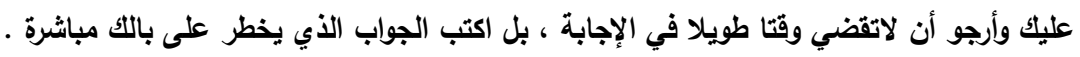

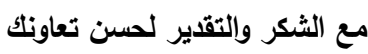

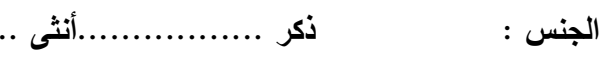

1

\begin{tabular}{|c|c|c|c|c|c|}
\hline ارفض بثدة & أوافق قليلا & أوافق أحيانا & أوافق تماما & الفقرات & $ت$ \\
\hline & & & & غالبا ما انهض متلهفا لأبدا حياتي من حيث انتهيت في اليوم السابق & 1 \\
\hline & & & & أحب التتويع الكثير في عملي & r \\
\hline & & & & يساع التظطيط المسبق في تجنب اغلب مشاكل الفرد المستقبلية & $r$ \\
\hline & & & & اليوم بعر بأني قادر على التغير مع ما قد يحدث غدا من خلال ما أقوم به & $\varepsilon$ \\
\hline & & & & أحب الجدل والمناقثة الجدية مع الآخرين & $\circ$ \\
\hline & & & & مهما حاولت أن ابذل من جهود فأنها ستذهب سدى & 9 \\
\hline & & & & اغلب الأثخاص الذين يعملون لكسب العيش مستظلون من قبل رؤسائهم & $\mathrm{v}$ \\
\hline & & & & لاتصل إلى أهد|فك مهما بذلت من جهود & $\wedge$ \\
\hline & & & & الثخص الذي نادرا ما يتغير تفكيره يكون معتمدا على أحكام ثابتة & 9 \\
\hline & & & & أجد سهولة التكيف حينما انتقل إلى مكان أخر & 1. \\
\hline & & & & اعتقل أن اغلب الأثياء التي تحدث في الحباة مقدرا لها أن تحدث & 11 \\
\hline & & & & افرح عندما يستشيرني الآخرين & ir \\
\hline & & & & عندما أضع الخطط أكون متأكدا أنني قادرا على تطبيقها علمياً & ir \\
\hline & & & & اعترف بالخطأ وأحاول التعلم والاستفادة منها & $1 \leqslant$ \\
\hline & & & & أتطع بواقعية للتقام في علمي & 10 \\
\hline & & & & أتحمل التجاوزات وإساءات الآخرين & 17 \\
\hline
\end{tabular}




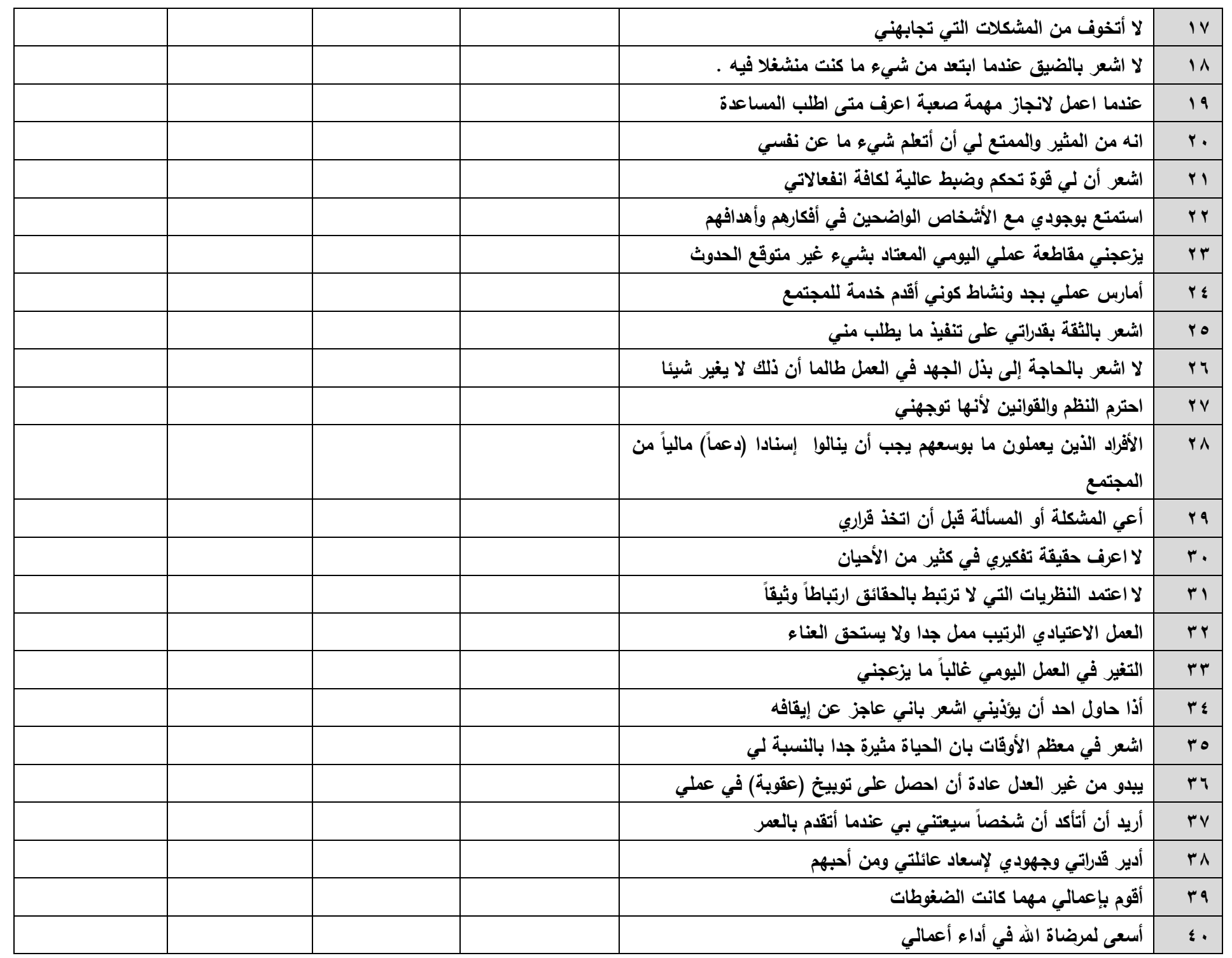

